\title{
Activities of mining and metallurgical industry enterprises of the Republic of Kazakhstan: environmental problems and possible solutions
}

\author{
Turgai Alimbaev ${ }^{1}$ Zhanna Mazhitova $^{2 *}$ Chinara Beksultanova ${ }^{3}$, \\ and Nazira Tentigul Kyzy \\ ${ }^{1}$ Buketov Karaganda State University, Universitetskaya Str. 28, 100026, Karaganda, Republic of \\ Kazakhstan \\ ${ }^{2}$ Astana Medical University, Beibitshilik Str. 49A, 010000, Nur Sultan, Republic of Kazakhstan \\ 3 I. Akhunbaev Kyrgyz State Medical academy, Akhunbaeva Str. 92, 720020, Bishkek, Kyrgyz \\ Republic
}

\begin{abstract}
The paper discusses the issues related to modern environmental problems that have arisen in connection with the activities of the mining and metallurgical industry enterprises of the Republic of Kazakhstan. The authors emphasize that due to the industrial progress of the mining and metallurgical industry, which is one of the main sectors of the republic's economy, the level of environmental pollution is increasing. The contributing authors prove by examples that, on the one hand, the growth of the economic potential of the mining and metallurgical industry and the transition to market mechanisms for the development of the economy have generated a large increase in the potential of the republic as a major exporter and leader among the world's raw material powers. On the other hand, the increase in industrial production led to a real threat of an environmental crisis in the republic. We conclude that it is possible to solve the environmental problems by improving measures to protect atmospheric air and increasing the efficiency of water resources use and protection. In addition, according to the authors, reduction in the chemical load on the soil, strengthening of the work on protection, reproduction and rational use of the plant and animal world, the introduction of treatment facilities and plants, especially in places of mining, will create a favorable environment for a significant improvement in environmental situation in the region.
\end{abstract}

\section{Introduction}

The mining and metallurgical industry is one of the main sectors of the economy of the Republic of Kazakhstan. A distinctive feature of the industry includes the variety of extracted minerals and, as a result, a large number of enterprises operating both in the field of exploration and exploitation of deposits, and in the sphere of material and technical support of subsoil use processes. From an economic point of view, an important feature of

* Corresponding author: mazhitova_69@mail.ru 
Kazakhstan's fossil resources is that they often lie close to the surface of the earth and, therefore, they are mined by a cheap open-pit method (in quarries). Furthermore, in some cases they are conveniently located for complex use. For example, in Central Kazakhstan, non-ferrous and ferrous metals, coking hard coals, limestones and refractory clays are located relatively close to each other. This combination of minerals is very favorable for the development of non-ferrous and ferrous metallurgy and the related chemical industry and mechanical engineering. The Republic of Kazakhstan occupies a leading position among the commodity powers of the world. The total volume of mining of solid minerals brought the republic to 13th place in the world among 70 mining countries. It should be noted that Kazakhstan plays an important role in the world market of copper, uranium, titanium, ferroalloys and steel. It is a monopolist in the Eurasian subcontinent for chromium, and has a significant impact on the regional market of iron, manganese, coal and aluminum. Mining is one of the main sectors of the economy of the Republic of Kazakhstan. It occupies a fairly good position globally in the following types of minerals. According to the data of the Statistics Committee of the Ministry of National Economy of the Republic of Kazakhstan (hereinafter referred to as the Statistics Committee of the RK) for 2018, the following quantities of main industrial products were produced in the mining sector: coal, including lignite and coal concentrate - 117.8 million tons; oil, including gas condensate 90.4 million tons; natural gas -55.5 billion cubic meters; iron ore -41.7 million tons; copper ores - 103.2 million tons; aluminum ores -6.1 million tons; gold-bearing ores 20.8 million tons; lead in lead concentrate -86.0 thousand tons; manganese ores -1.4 million tons; chromium concentrate -4.9 million tons. At the beginning of 2018, 866 subsoil use contracts were in effect in Kazakhstan, including 484 for solid minerals.

\section{Discussion of the results}

\subsection{To the statement of the problem}

One of the important directions of the domestic policy of sovereign Kazakhstan is the attempt to solve the environmental problems of the republic related to mining $[1,2]$. At present, the mining and metallurgical industry is the second most important sector after the oil and gas industry. It is demonstrating active growth: the productivity of leading mining enterprises has increased; the demand for rare-earth metals has increased, the commodity price situation has changed upward; mining of iron, aluminum and copper ores has significantly increased; prospective geological mineral reserves continue to attract investors. The priority areas of investment are subsoil use objects of copper, polymetals (lead, zinc), gold, iron, manganese, chromites, aluminum (bauxites), and phosphorites. Demand for products manufactured by the mining and metallurgical industry is determined by the growth in construction volumes in the world. The interest is supported by an increase in demand from foreign partners. According to the Statistics Committee of the RK, investments in the mining industry in 2018 compared to the previous year increased by $40.4 \%$ and amounted to $4,499.6$ billion tenge $(68.5 \%$ of the total investment in fixed assets), including own funds of organizations amounted to 4,327.9 billion tenge, bank loans - 6.1 billion tenge, borrowed funds of non-residents - 45.3 billion tenge and other borrowed funds -165.6 billion tenge. In $2018,463.8$ billion tenge or $10.3 \%$ of the total investment in the mining industry was directed to the extraction of metal ores, 85.5 billion tenge $(1.9 \%)$ were invested in the extraction of coal and lignite, investments in other mining industries industry amounted to 18.7 billion tenge $(0.4 \%)$. As of January 1,2019 , 3,835 legal entities were registered in the country's mining sector, of which 17 are stateowned, 273 are joint ventures, and 354 are foreign companies. 
Major enterprises of the country's mining and metallurgical industry include Eurasian Resources Group (ERG), Kazakhmys Corporation LLC, Kazzinc Ltd, ArcelorMittal Temirtau JSC, NAC Kazatomprom JSC, Ust-Kamenogorsk Titanium-Magnesium Plant JSC, Temirtau Electro-Metallurgy Plant JSC, Taraz Metallurgical Plant LLP, KSPSteel LLP, Zhairem Mining and Concentrating Complex JSC, Sokolov-Sarybai Mining Production Association (SSGPO) JSC, Kazakhaltyn Mining-Metallurgical Concern JSC, KAZ Minerals PLC, etc. In 2018, the republic produced industrial products totaling $27,576.1$ billion tenge, including the mining industry for $15,202.2$ billion tenge. The industrial production index in the mining industry was $104.6 \%$. Production of coal and lignite $(102.5 \%)$, iron ore $(106.5 \%)$, non-ferrous metal ores $(104.3 \%)$, gold ore $(102.9 \%)$, chromium concentrate (107.6\%), ferroalloys (107.9\%), refined lead (100. 9\%) and refined copper $(102.8 \%)$ have been increased.

According to the Statistics Committee of the RK for 2018, export prices for iron ore increased by $26 \%$, for manganese ore - by $22.1 \%$, for copper - by $16.8 \%$, for ferroalloys by $14.3 \%$, for rolled ferrous metals - by $10.5 \%$, for coal - by $6.1 \%$. They decreased for chromium ores by $13.9 \%$, for lead - by $12.4 \%$, and for zinc - by $8 \%$ [3, p. 32].

The Republic of Kazakhstan is the world's largest producer of beryllium, niobium, gallium, technical thallium, titanium sponge, rhenium, uranium, coal, silver, zinc and alumina. In 2017, Kazakhstan produced $39.3 \%$ of the world's uranium production, followed by Canada (22\% of world production) and Australia (9.9\%). The three leaders accounted for $71.2 \%$ of global uranium production. According to the World Nuclear Association, in 2017 five major global uranium producing companies accounted for $65 \%$ of global production. The largest of them, NAC Kazatomprom JSC, provided $20 \%$ of the world's uranium production. Export orientation and competitiveness of the country's mining and metallurgical industry, along with meeting the needs of the domestic market, is a key indicator of stable activity over recent years [4, p. 41].

\subsection{Ecological crisis in the atmosphere and its impact on society}

The concentration of coal, non-ferrous and ferrous metallurgy enterprises in Kazakhstan has led to a significant level of pollution of all components of the natural environment. As a result, Kazakhstan has traditionally been among the regions with the highest proportion for the emission of pollutants into the atmosphere and the polluted wastewater discharge. Nevertheless, the most important components that determine the current general environmental situation are the real state of the air and water basins, and the consumption of water resources. Due to the rapid development of the mining and metallurgical industry, air pollution has turned into one of the most difficult environmental problems of our time in recent decades. Despite the fact that Kazakhstan is not the main supplier of pollutants to the atmosphere compared to industrialized countries, according to the Ministry of Environment and Water Resources of the Republic of Kazakhstan, at the end of the 20th century the level of air pollution in cities remained comparatively high by international standards. Statistics of the last decade of the 20th century demonstrated the reduction of emissions of harmful substances into the atmosphere from stationary sources. Nevertheless, the degree of anthropogenic pressure on the environment remained quite high. The level of air pollution in the cities of Temirtau and Balkhash was 1.1-2.5 times higher for a number of ingredients than the average for Kazakhstan. The largest contribution to the overall indicators was made by the enterprises of the coal industry - non-ferrous and ferrous metallurgy $-5 \%$. In accordance with this, five cities with the most intense air pollution were identified in the region - Temirtau, where the chemical and metallurgical industries are concentrated, Balkhash, Zhezkazgan, and Ust-Kamenogorsk (non-ferrous metallurgy), Karaganda, Shakhtinsk and Ekibastuz (coal industry), and Saran (coal and chemistry). 
Air emissions still remain high and amount to 660 thousand tons per year or an average of $550 \mathrm{~kg}$ per inhabitant of the region. The cities of Karaganda, Ust-Kamenogorsk and Temirtau still have the most polluted environment, where atmospheric emissions are 123 thousand tons and 370 thousand tons respectively. In some cases, the content of harmful substances such as phenols and ammonia are several times higher than the maximum permissible concentrations. The most powerful pollutants remain Ispat-Karmet and thermal power industry, which account for $75 \%$ of the emissions of the region's enterprises.

In 2018, black snow was recorded in Temirtau. As a result, the mobile laboratory of the RSE "Kazhydromet" carried out studies of atmospheric air and soil. In the course of research, the laboratory recorded an excess of the maximum permissible concentrations (MPC) of harmful substances: ammonia up to 3.9 MPC; hydrogen sulfide up to 5 MPC; hydrocarbon up to $2.2 \mathrm{MPC}$, carbon monoxide and nitrogen dioxide up to $5 \mathrm{MPC}$. The pollution is local. The sources of increased concentrations of carbon and soot in black snow included enterprises of the fuel and energy complex. The analysis of samples in sediments revealed a large amount of titanium, barium, vanadium, and cadmium. The analyses demonstrated an increased iron content, which indicates the contribution of the metallurgical industry enterprises to the general pollution. According to the research of the RSE "Kazhydromet", the main causes of black snow were regulated emissions of industrial enterprises during periods of adverse weather conditions. Based on the Decree of the Prosecutor's Office of the Karaganda Oblast, the Department of Ecology of the Karaganda Oblast conducted an unscheduled audit of the activities of the alleged source of black snow - Arcelor Mittal Temirtau JSC. The audit revealed the facts of exceeding the standards of emissions into the environment in the period from 2016-2017 and the first quarter of 2018. After a series of litigations in 2019, a decision was made to recover environmental damage from Arcelor Mittal Temirtau JSC in the amount of 1.3 billion tenge. The company is also held administratively liable. To ensure the public to solve environmental problems in the Karaganda oblast, in 2018 the Council on Environmental Protection was created under the chairmanship of the akim of the region (Council). The Council included representatives of non-governmental organizations, independent environmentalists, as well as heads of large industrial enterprises and government bodies. The Council is called to unite the efforts of the public, business, science and government bodies in making decisions in the field of ensuring a safe environment and improving the environmental situation in the region $[5, \mathrm{p}$. 314].

One of the factors that have a negative impact on the ecological situation in the region is the release of methane into the atmosphere. The priority for the protection of atmospheric air was and remains the introduction of the latest technological processes, environmentally friendly and waste-free technologies and, in general, clean production. At a number of enterprises, measures to use low-ash coals are not being implemented, which leads to an increased emission of ash into the atmosphere. However, due to the large difference in cost, high-ash coals are still widely used, especially in thermal power plants. This is just one example where the economy prevails over the environment and leads to the fact that the ecological well-being of the region and the health of the people subsequently cost more than such an economy. The level of air pollution in the region is determined mainly by 15 large enterprises. The major environmental pollutants are coal industry enterprises (ArcelorMittal Temirtau JSC, ShubarkolKomir JSC); mineral mining enterprises (Kazakhmys Corporation LLC, Zhairem Mining and Concentrating Complex JSC, NovaZink LLP, Kazchrome JSC); boiler plants of heat and power plants (Karaganda Energy Center LLP (TPP-1, TPP-3); building materials manufacturing enterprises (Central Asia Cement JSC; heat and power industry enterprises (Kazakhmys Energy LLP); metallurgical industry enterprises (Kazakhmys Energy LLP, Temirtau Electro-Metallurgical Plant JSC). According to the Statistics Committee, the volume of emissions from stationary sources in 
2018 amounted to 587.5 thousand tons, in 2017 the volume of emissions amounted to 590.0 thousand tons. In 2018, there was a little overall reduction in emissions, but overall emissions remain at a high level. The reduction in emissions in the region was conditioned by a decrease in sintering, blast furnace and coke and chemical production of ArcelorMittal Temirtau JSC due to emergency situations; suspension of activities of enterprises of Kazakhmys Smelting LLP in May 2018. The main pollutants in the Karaganda oblast are carbon monoxide, sulfur dioxide, nitrogen dioxide and particulate matter. Emission volumes of the main pollutants are given in table 1 [6].

Table 1. Emissions volume of pollutants into the air from stationary sources.

\begin{tabular}{|c|c|c|}
\hline Industrial air emissions & $\begin{array}{c}2017 \\
\text { (thousand tons) }\end{array}$ & $\begin{array}{c}2018 \\
\text { (thousand tons) }\end{array}$ \\
\hline Sulfur Anhydride Emissions & 239,5 & 250,9 \\
\hline Nitrogen dioxide emissions & 47,8 & 48,1 \\
\hline Particulate emissions & 119,6 & 120,6 \\
\hline Carbon monoxide emissions & 168,8 & 149,0 \\
\hline
\end{tabular}

\subsection{Water resources ecology}

At present the important factor determining not only the environmental situation, but also the development of productive forces, is the state of water resources. Currently it is of serious concern. The RSE "Kazhydromet" observations of surface water pollution in the territory of the East Kazakhstan Region were carried out at 13 water bodies (the Kara Ertis, the Yertis, the Breksa, the Tikhaya, the Ulbi, the Glubochanka, the Krasnoyarka, the Oba, the Buktyrma, the Emel, the Ayagoz, the Markakol, the Buktyrma and the UstKamenogorsk reservoirs). Water quality in the examined water bodies is classified as follows: the Kara Yertis, the Yertis, the Buktyrma, the Oba, the Ayagoz, the Emel rivers, Markakol lake, Buktyrma and Ust-Kamenogorsk reservoirs are of "moderate pollution" water; the Breksa, the Tikhaya, the Ulbi, the Glubochanka rivers are of "high pollution level" water; the Krasnoyarsk river is of "extremely high pollution level" water. Compared to 2017, the water quality in the Kara Yertis, the Buktyrma, the Yertis, the Breksa, the Tikhaya, the Ulbi, the Glubochanka, the Oba, the Emel, the Ayagoz rivers, Buktirma reservoir, Ust-Kamenogorsk reservoir did not change significantly. However, the water quality in the Krasnoyarka river and Markakol lake worsened. According to the observations of the RSE "Kazhydromet", in 2018, 68 cases of high pollution (hereinafter HP) and 5 extremely high pollution (hereinafter EHP) were recorded in the territory of the East Kazakhstan region: the Breksa river (Ridder) - 12 cases of HP, the Tikhaya river (Ridder) - 10 cases of HP, the Ulby river (the cities of Ridder and Ust-Kamenogorsk) - 19 cases of HP and 3 cases of EHP, the Glubochanka river (Belousovka and Glubokoe villages) - 14 cases of HP and 1 case of EHP, the Krasnoyarka river (Predgornoye village) - 13 cases of HP and 1 case of EHP [7, p. 54]. These data are demonstrated in table 2.

Table 2. The number of cases of HPL and EHPL in the region for 2017-2018 [8, p. 403].

\begin{tabular}{|c|c|c|c|c|}
\hline \multirow{2}{*}{ Water body } & \multicolumn{2}{|c|}{ High pollution cases } & Extremely high pollution cases \\
\cline { 2 - 5 } & 2017 & 2018 & 2017 & 2018 \\
\hline Breksa River & 12 & 12 & - & - \\
\hline Tihaya River & 9 & 10 & - & - \\
\hline Ulbi River & 20 & 19 & - & 3 \\
\hline Glubochanka River & 26 & 14 & - & 1 \\
\hline Krasnoyarka river & 11 & 13 & 1 & 1 \\
\hline
\end{tabular}


The main causes of HP and EHP in the rivers of the East Kazakhstan oblast are the high technogenic load on the part of mining enterprises and historical pollution (rock dumps, tailings). Since 2017 the number of cases of HP in the Breksa, the Tikhaya, the Ulbi, and the Krasnoyark rivers has changed by one or two units, its quantity in the Glubochanka River has significantly decreased from 26 to 14 . The Krasnoyark, the Glubochanka, the Ulbi rivers continue to be the most polluted based on chemical indicators. A high-water pollution index of these rivers has been maintained over the past few years. The main pollutants are zinc, manganese, copper, cadmium, and iron. The water quality characteristics in these rivers correspond to the "high" and "extremely high" pollution levels. The pollution of the Brexa, the Tikhaya, and the Ulbi rivers is caused by historical pollution from spoil heaps, which are currently in state ownership, as well as dumps of Kazzinc LLP. The Krasnoyarka, the Glubochanka (near the Tishinsky mine, Ridder) are influenced by the existing enterprises of the Vostoktsvetmet LLP mining complex. The main source of river pollution is the mine water of the Irtysh mine. In the river the drainage of the sludge storage pit of the Irtysh mine and the Berezovsky tailing pond flows into the Krasnoyarka River, spilling from the Kapitalnaya mine, which is state-owned. The pollution of the Glubochanka River is mainly due to historical pollution of the dump. Between 2005-2018 the East Kazakhstan Regional Akimat issued 84 resolutions on the establishment of water protection zones and belts, including the cities of Ust-Kamenogorsk, Semey, Zyryanovsk, Ridder, Shemonaikha, the coasts of Bukhtarminsky, UstKamenogorsk and Shulba reservoirs, Alakol lake and others. The total length of the established water protection zones is $1874 \mathrm{~km}$, the area is $67861 \mathrm{ha}$. The total length of the established water protection belts is $2463 \mathrm{~km}$, the area is 14792 hectares. In order to provide drinking water and modernize the drinking water supply system of settlements, the earlier prospecting and exploration work of underground waters for 40 settlements of the region was completed and additional exploration of 4 underground water deposits (Taskeskenskoye, Kamyshinskoye, Targynskoye and Kuraylinskoye) was completed in 2018. Furthermore, prospecting and exploration work on 17 rural settlements of the region and additional exploration of one underground water field began in 2018. In order to prevent and eliminate flood threats, "A set of measures for the prevention and elimination of flood threats for 2017-2020" Roadmap (hereinafter referred to as the Roadmap) and the Plan for the conservation, accumulation and distribution of flood water and restoration of pasture water for livestock (hereinafter referred to as the Plan) were developed and approved. The Roadmap for the East Kazakhstan Oblast includes 80 events, including 21 events in 10 oblast regions for 2017; 22 events in 7 oblast regions for 2018. The Plan for the East Kazakhstan Oblast includes 60 measures for the repair of existing communal owned water storage tanks. The repairs of 45 drives were carried out at the expense of the regional budget in 2018 [9, p. 74].

\subsection{Soil ecology}

Soil pollution in the Republic of Kazakhstan is an urgent problem and has the status of not only republican, but also international significance. Soil and vegetation cover in the large areas of the republic is being polluted with heavy metals, oil products and complex organic substances, which is associated with emissions from industrial enterprises and transport. The main sources of pollution are air emissions, solid and liquid waste from mining and metallurgical enterprises. Typically, areas of significant pollution have a small area along roads, near industrial enterprises and airfields, and are associated with the transboundary transport of heavy metals, sulfur oxides and nitrogen. The most dangerous type is radioactive contamination. There are 6 large uranium-bearing provinces, many small deposits and ore occurrences of uranium in the Republic of Kazakhstan, which cause an 
increased level of natural radioactivity. Acute environmental challenges concern not only the territory where the bank of low enriched uranium is located in Ust-Kamenogorsk, but also the use of radioactive materials in the country. Large development of uranium soil was carried out in the Mangistau region. During the period of activity of the uranium mining industry in Kazakhstan, about 200 million tons of radioactive waste was generated. The tailings of toxic and radioactive waste remain the most acute problem. As a result of many years of operation of the lead plant (JSC Yuzhpolymetal PC) in the territory of Shymkent city, the permissible concentration of lead in the soil $(32 \mathrm{mg} / \mathrm{kg})$ has exceeded 16.5 times.

Significant pockets of anthropogenic disturbances and soil pollution are widespread in the industrial regions of the republic. Centers of soil pollution from industrial enterprises have been formed on the outskirts of the cities of Ust-Kamenogorsk, Ridder, Zhezkazgan, Shymkent, and Karaganda. The situation with industrial waste, including technogenic mineral formations (hereinafter referred to as TMF), remains extremely unsatisfactory. To date, there are 775 solid TMO facilities in the republic, in which about 34 billion tons are accumulated, and there is a tendency for their annual growth. In addition to the problems associated with industrial and toxic waste, there is the issue of storage and processing of increasing volumes of household waste in almost all settlements of the republic, especially in large cities. The development of the mining industry has intensified the process of land pollution with toxic substances. The largest shares of wastes from the mining and processing complexes belong to Karaganda oblast - 29.4\%, East Kazakhstan oblast 25.7\%, Kostanai oblast $-17 \%$ and Pavlodar oblast - 14.6\%. In Kostanai, Karaganda, Aktobe, East Kazakhstan, Pavlodar, Zhambyl, West Kazakhstan oblasts, enterprises engaged in the extraction of coal, ferrous metals and phosphorites, accumulated significant waste dumps of mining and processing industries. According to the land balance as of November 1, 2018, there are 248.42 thousand hectares of disturbed land in the Republic, where overburden and rock dumps, tailing dumps, ash dumps, and quarries of coal and mining developments are located. The largest number of disturbed lands is in Karaganda, Kostanay, Mangistau, Akmola, East Kazakhstan, Aktobe, and Pavlodar oblasts. There are environmentally hazardous impact zones in all industrial regions: heaps, dumps, quarries, boreholes, mining waste with a total area of more than 60 thousand hectares, which constantly contaminate the soil. As a result of the activities of only non-ferrous metallurgy enterprises, more than 22 billion tons of waste was accumulated, including about 4 billion tons of mining waste, as well as the toxic wastes such as more than 1.1 billion tons of enrichment waste and 105 million tons of metallurgical processing waste. The areas occupied by non-ferrous metallurgy waste accumulators amount to about 15 thousand ha, of which 8 thousand hectares include rock dumps, about 6 thousand ha include tailings of enrichment plants and more than 500 ha belong to dumps of metallurgical plants. Waste volumes in the iron and steel industry and the chemical industry are of the same order. The lands are contaminated with compounds of copper, zinc, cadmium, lead, and arsenic in the East Kazakhstan oblast. Toxic waste is disposed of in landfills that do not meet sanitary and environmental requirements. Anomalies of lead cover the territories of Shemonaikhinsky, Glubokovsky and Zyryanovsky regions. The most disadvantaged is the area in the triangle between the cities of Ust-Kamenogorsk, Ridder and Zyryanovsk. As a result of the constant increase in the volume of accumulated waste due to the undeveloped places of their storage and disposal, there is a migration of pollutants into the environment. In the Karaganda region, land pollution is associated with waste from the mining and metallurgical industries.

There are over 350 landfills for industrial and household waste in the region. Excess emissions from the Balkhash Mining and Metallurgical Combine have led to soil pollution by copper, zinc, cobalt, cadmium and lead. Technologically-polluted lands of Kostanay oblast are widespread in industrial zones of cities, zones of mining and processing of minerals. The issue of environmental pollution in the region with ash dumps of the Troitsk 
Hydroelectric Power Station and tailings ponds of the Sokolov-Sarybai Mining Production Association (SSGPO) JSC is acute. Disposal, neutralization, burial, transboundary transportation of waste are some of the most pressing problems in the country. Toxic waste is still stored in various storage facilities, often without observing relevant environmental standards and requirements. As a result of this, the soil, groundwater, and surface waters of many regions are subject to intense pollution. In general, more than 26 billion tons of solid waste has been accumulated over the long-term period of intensive development of all industries of Kazakhstan, including the mining and metallurgical complex, which is annually replenished by another 1 billion tons in dumps. Most of them (58\% or 15.1 billion tons) falls on waste from the mining and metallurgical industries, which are considered as an independent raw material base. In non-ferrous metallurgy (copper-aluminum, lead-zinc, gold-rare-metal industries) the total amount of waste reaches more than 5 billion tons, of which associated mining and stripping rocks comprise $72 \%$, enrichment tailings comprise $26 \%$ and metallurgical processing comprises $1,6 \%$. The land area occupied by waste is more than 13 thousand hectares. The total amount of accumulated waste in the ferrous metallurgy of Kazakhstan (iron ore, chromium ore and manganese ore industries) is more than 6.2 billion tons, of which associated mining and stripping comprises $92.8 \%$, enrichment constitutes $6.1 \%$ and metallurgical processing comprises $1.1 \%$. The land area occupied by waste is more than 15 thousand ha [10, p. 153-160].

In the light of the foregoing, the problem of the careful use of our national heritage natural resources, through which $60-70 \%$ of the state budget is formed (apparently this trend will continue for the next 10-15 years), becomes particularly relevant. This is explained not only by the fact that constantly developing and expanding private entrepreneurship, its essence and the ultimate goals of activity of which are maximizing profits in the shortest possible time, do not concern the issues of careful spending of natural resources, in this case, mineral and raw materials, but also that the current state mechanism for ensuring the rational use of mineral resources is not perfect.

\section{Conclusion}

Today, Kazakhstan is one of the most environmentally disadvantaged regions in Eurasia, more than 21 billion tons of waste has accumulated on its territory, with an annual increase of about 1 billion tons. Dumps and tailings have destroyed almost 200,000 hectares of land, ecologically dangerous zones have destroyed yet 60,000 hectares in Kazakhstan. Ecological pressure on the environment by waste from mining and metallurgical enterprises is very high in these areas, and the relationship of ecology with public health is direct. There is no region where pollution of the atmosphere, soil, surface and groundwater and, as a consequence, food due to technogenic pollution, does not affect people's health (there are abnormalities of the immune status, increased levels of blood and blood-forming organs diseases, allergic diseases in the areas where non-ferrous and ferrous metallurgy are located). A complex combination of natural and anthropogenic impacts, among which the most significant and problematic one is the industrial impact, is the basis for forecasts regarding further exacerbation of environmental problems.

In this regard, the following promising directions for optimizing the state of the environment appear to be most important: 1. Improving measures for the protection of atmospheric air through the introduction of sewage treatment facilities and plants. 2 . Improving the efficiency of use and protection of water resources, as well as improving the condition of small rivers, reservoirs, monitoring the status of groundwater. 3. Solving the problems of rational use of land, including protection against wind and water erosion, flooding, waterlogging and salinization. 4. Reducing the chemical load on the soil. 5. Creating infrastructure for waste processing; expansion of the network of nature reserves, 
national parks. 6. Strengthening the protection, reproduction and rational use of the plant and animal world. 7. Improving the health and quality of life of the population. The priority area of activity of state bodies in these conditions should be the active use of economic, legal and organizational methods of influencing the emerging economic system, its maximum environmental friendliness in order to balance the development of heterogeneous processes: the country's economic development and creation of a favorable natural environment for human life and health.

In our opinion, it is necessary to develop and stimulate the implementation of lowwaste, resource and energy-saving technologies and processes. Based on the achievements of scientific and technological progress, there should be the intensification of research and development work, environmental investment projects. Particular attention should be paid to the environmental awareness of nature users and the formation of appropriate public opinion, since the changes taking place in the world necessitate the formation of a holistic humanistic worldview in relation to nature, in which universal human values will receive priority importance. At the same time, the specificity and variety of environmental and economic transformations require a differentiated approach to the development and implementation of an economic mechanism for nature management. This confirms the importance of developing long-term environmental programs as the main component of environmental management and environmental protection in long-term plans for socioeconomic development at the national, regional and local levels.

\section{References}

1. T. Alimbaev, Zh. Mazhitova, B. Omarova, Zh. Nurkina. IOP Conference Series: Materials Science and Engineering, 663, 1-5 (2019)

2. T. Alimbaev, Zh. Mazhitova, B. Omarova, B. Kamzaev, K. Atanakova. E3S Web of Conferences, 157, 1-8 (2020)

3. Monthly industry journal Astana, 123, 3210 (2018)

4. Monthly industry journal Astana, 3, 117 (2018)

5. National report on the state of the environment and on the use of natural resources of the Republic of Kazakhstan for 2018 Astana, 314 (2019)

6. The newsletter on the state of the environment of the Republic of Kazakhstan NurSultan, 01, 243 (2020)

7. A. Adryshev. Materials of the Internet-conference "Dynamics of Research - 2008", 23, 54 (2008)

8. National report on the state of the environment and on the use of natural resources of the Republic of Kazakhstan for 2018 Astana, 407 (2019)

9. Zh. Uzdenbaeva. Bulletin of the D. Serikbayev EKSTU - Ust-Kamenogorsk, 1, 74 (2006)

10. V.N. Umanets, G.G. Bugayeva, V.S. Zavalishin, Scientific and technical support for mining: materials collection of D. Kunayev Mining Institute, 63, 153-160. Almaty (2002) 